\title{
Variabilidade Temporal da Radiação Solar Durante o Experimento GOAmazon 2014/15
}

\author{
Alice dos Santos Macedo ${ }^{1}$, Gilberto Fisch ${ }^{2}$ \\ ${ }^{1}$ Centro de Previsão do Tempo e Estudos Climáticos, Pós Graduação em Meteorologia, \\ Instituto Nacional de Pesquisas Espaciais, São José dos Campos, SP, Brasil. \\ ${ }^{2}$ Divisão de Ciências Atmosféricas, Instituto de Aeronaútica e Espaço, \\ São José dos Campos, SP, Brasil.
}

Recebido em 6 de Abril de 2017 - Aceito em 24 de Julho de 2017

\begin{abstract}
Resumo
O presente trabalho estudou a variabilidade temporal das 3 componentes da irradiância solar (global, direta e difusa) na região de Manacapuru, distante 66 km de Manaus-AM, dentro do âmbito do projeto GOAmazon 2014/15, analisando dados relativos aos anos de 2014 e 2015. Também foram analisados dados de cobertura de nuvens e precipitação do mesmo período. Observou-se, de modo geral, que os valores das frações de nuvens foram semelhantes entre os dois anos analisados, situando-se entre valores típicos de 20-25\% (estação seca) e 35-40\% (estação chuvosa). São apresentados valores típicos das irradiâncias solar global, direta e difusa para diferentes escalas de tempo (horárias e sazonal), bem como as variações destes valores entre os anos 2014-2015 (escala interanual). São também apresentados as interrelações destas 3 componentes para os valores médios horários e mensais e observa-se que as irradiâncias solar global e direta são diretamente relacionadas entre si e inversamente relacionadas com a contribuição difusa. Finalizando, é discutido como o evento EN 2015 impactou as medidas das 3 componentes da irradiância solar a superfície, associando com a menor ocorrência de nuvens/chuva e da presença maior de aerossóis.
\end{abstract}

Palavras-chave: global, difusa, direta, cobertura de nuvens, medida direta.

\section{Temporal Variability of Solar Radiation During the GOAmazon 2014/15 Experiment}

\begin{abstract}
The present work studied the temporal variability of the three components of solar irradiation (global, direct and diffuse) at the Manacapuru region, $66 \mathrm{~km}$ distant from Manaus-AM, within the scope of the GOAmazon 2014/15 project, analyzing data for the years of 2014 and 2015. Also it was analyzed the cloud cover data and precipitation. In general, the cloud cover for both years were similar and their typical values are $20-25 \%$ (dry season) and $35-40 \%$ (wet period). The typical values of global, direct and diffuse solar irradiance were presented for different time scale (hourly and seasonal) as well as variations for the years 2014 and 2015 (interannual scale). The interrelationships amongst the 3 components for hourly and monthly values were presented and it can be noticed that global and direct solar irradiances were directly related although both were inversely correlated with the diffuse solar irradiance. Finally, the ENSO 2015 event was discussed and how it was impacted, the measurements as it had lower cloud cover and rain the higher aerosol concentration. Keywords: global, diffuse, direct, cloud cover, direct measurement.
\end{abstract}

\section{Introdução}

A Amazônia é a maior floresta tropical do mundo e está situada na parte norte da América do Sul com cerca de 5,5 milhões de $\mathrm{km}^{2}$. Possui riquíssima biodiversidade com a presença de milhares de espécies animais e vegetais, tornando grande o interesse em estudos ambientais da região. O clima amazônico deve-se a combinação de vários fatores, sendo o mais importante a disponibilidade de energia solar, pois esta incide a superfície com maior intensidade na faixa equatorial. A atmosfera tropical caracte-

Autor de correspondência: Alice dos Santos Macedo, alicesmacedo@gmail.com. 
riza-se também por possuir um grande conteúdo de vapor d'água na atmosfera, devido aos altos fluxos de calor latente (evapotranspiração) provenientes da superfície. Esta combinação de fatores é crucial para o disparo da convecção, formação de nuvens e de chuvas. Deste modo, mudanças na formação, estrutura e área de cobertura de nuvens também alteram a irradiância solar incidente em superfície e podem causar alterações no perfil termodinâmico da atmosfera, modificando os fluxos de calor sensível e latente da superfície, altura da camada limite, correntes atmosféricas ascendentes e descendentes, taxas de evaporação e os padrões de circulação regional, entre outros. Além disso, a região Amazônica é fortemente influenciada por oscilações interdiurnas, intra-sazonais e interanuais e, conseqüentemente, por interações entre estas diferentes escalas. As oscilações interanuais apresentam forte variabilidade da cobertura de nuvens e chuva e estão associadas a episódios de El Niño (EN) e La Niña (LN), segundo Alves et al. (2007). Apesar da importância da irradiância solar, os estudos que quantificam o fluxo de radiação solar que atinge a superfície ainda são poucos (Brinkmann et al., 1971; Costa Azevedo et al., 1974; Vila Nova et al., 1976, 1978,Feitosa et al., 1998, Pavão et al., 2014) e com pouca extensão temporal de suas medidas (por exemplo Culf et al., 1996). Além disso, são raros os artigos que possuem medidas das componentes direta (Almeida et al., 1979) e/ou difusa (Goldman et al., 1989). Recentemente, Macedo (2016) fez uma compilação completa destas informações já publicadas.

Durante o período de 2014/2015, ocorreu em Manacapuru - AM, o experimento Green Ocean Amazon 2014/15 (GOAmazon 2014/15), no qual foram coletados alguns dados que jamais haviam sido medidos na região. Este experimento estendeu-se de janeiro 2014 a dezembro de 2015 e foi projetado para permitir o estudo de aerossóis, bem como os fluxos de superfície influenciam os ciclos de formação da nuvem e seu tempo de vida, incluindo interações nuvem-aerossol-precipitação (maiores informações estão em Martin et al., 2016, 2017). Estas observações forneceram um conjunto de dados que podem ser utilizados em parametrizações de modelos de floresta tropical para aerossóis orgânicos, esquemas de nuvens e de convecção, componentes vegetação terrestre e como os dados podem ser perturbados por poluição oriunda da cidade de Manaus-AM. Este trabalho irá avaliar parte dos dados coletados pelo experimento, contribuindo para um maior conhecimento da variabilidade temporal do elemento climático irradiância solar na região, analisando sua interação com nuvens, precipitação e aerossóis. Este tipo de informação contribuirá como uma referência consistente para estudos futuros, no que diz respeito ao ciclo diário (valores mensais horários e integrais diários), bem como viabilizar estudos de validação de modelos numéricos e/ou estimativas feitas por satélites. Também contribuí para análise de impacto de redução de valores à superfície em eventos de El Niño, sendo uma aplicação prática para levantamento de potencial de energia solar. Ressalta-se a que não há, para a região, este tipo de informação para um período de tempo longo (23 meses contínuos).

\section{Material e Métodos}

O estudo se desenvolveu no sítio T3 $\left(3,21297^{\circ} \mathrm{S}\right.$; $\left.60,59805^{\circ} \mathrm{W}\right)$, que foi o ponto principal de coleta de dados do experimento GOAmazon 2014/15, situando-se na Fazenda Exata em Manacapuru-AM, a aproximadamente $66 \mathrm{~km}$ de distância ao sudoeste de Manaus. A vegetação do município é predominantemente de formação arbórea esparsa, tendo ao seu redor um relevo composto por lagos e ilhotes. Os ventos são predominantemente de nordeste na região, especialmente na estação chuvosa e com uma pequena rotação para leste na estação seca (Martin et al., 2016).

Os dados utilizados neste trabalho foram, em sua maioria, coletados de 01 de janeiro de 2014 até 30 de novembro de 2015 (quando alguns instrumentos foram desmontados). $\mathrm{O}$ acesso a todos os dados do Atmospheric Radiation Measurement (ARM) é público e foi garantido através de um cadastro no site. Foram utilizados dados de irradiância solar global, direta e difusa. De forma complementar foram analisados dados de cobertura de nuvens, precipitação, quantidade de queimadas e de aerossóis.

Para a análise da irradiância solar utilizou-se dados da plataforma denominada SKYRAD que é composta de três sensores para as medições contínuas, minuto a minuto, de irradiância solar global, difusa e direta. A decomposição da irradiância solar direta foi necessária devido ao piroheliômetro estar acoplado ao rastreador solar que captura a irradiância solar direta, sendo necessária sua decomposição relativa ao plano horizontal. Esta decomposição foi realizada multiplicando-se a irradiância solar direta medida pelo instrumento pelo cosseno do ângulo zenital de cada instante de medida. Avaliou-se o ciclo diário médio da radiação solar mensal da irradiância solar global, difusa e direta à superfície, para intervalos de trinta minutos no período diurno (entre 6 e 18 horas local). Também obteve-se os valores integral média mensal e desvio padrão das irradiância global e suas componentes direta e difusa.

Para medidas de cobertura de nuvens foi utilizado o instrumento Total Sky Imager (TSI-600) que é um imageador que processa, em tempo real, as condições de nebulosidade do céu. Este instrumento possui uma calota convexa espelhada sobre uma base, onde está fixado um braço que sustenta uma câmera apontando para o centro da calota. Deste modo ele capta uma série de imagens de fração de nuvens no céu durante as horas de brilho solar. A partir dos valores de fração de céu coberto por nuvem foram calculadas as mensais médias entre 6 e 18 horas local. A importância principal destes dados é compreender o ciclo anual da cobertura de nuvens e verificar sua interação na atenuação da irradiância solar a superfície. Os dados de aerossol 
foram utilizados para quantificar de que modo as queimadas que ocorreram no período seco podem ter influenciado as medidas de irradiância solar à superfície.

\section{Resultados}

\subsection{Chuva e cobertura de nuvens}

A Fig.1 mostra o ciclo sazonal da precipitação, através dos valores acumulados diários, ao longo dos anos 2014 e 2015. Observou-se que o ano de 2015 foi mais seco (em torno de $20 \%$ do total anual) em relação a 2014 , principalmente nos meses de agosto a outubro, como resultado à ocorrência de um evento de EN (Macedo, 2016). Este evento (El Nino 2015/2016) foi considerado de grau de alta intensidade, semelhante aqueles que ocorreram entre 1982/83 e 1997/98 (ECMWF, 2017). Ressalta-se que os dados utilizados para a composição da Fig. 1a, ano de 2014, foram fornecidos por um pluviômetro para o período de janeiro a setembro de 2014 e por um laser disdrômetro para o período de outubro a dezembro de 2014. O pluviômetro mede o acumulado de chuva em um coletor com a taxa amostral (de uma medida por minuto) determinada pelo fabricante. $\mathrm{O}$ disdrômetro mede o acumulado de chuva através do nível perturbação no feixe do seu laser quando a gota o atravessa, sendo que a taxa amostral foi de uma observação por minuto. Para a composição da Fig. 1b, referente ao ano de 2015, utilizou-se apenas dados de um disdrômetro.

Na Fig. 2 são mostrados os valores médios mensais de fração de nuvem de abril de 2014 a novembro de 2015. Observou-se, de modo geral, que os valores das frações de nuvens foram semelhantes entre os dois anos analisados, situando-se entre valores típicos de 20-25\% (estação seca) e de $35-40 \%$ (estação chuvosa). Este resultado aproxima-se dos valores encontrados por Machado et al. (2004) que, em estudo com dados climatológicos derivados de satélite, obtiveram que a fração de nuvem varia de 15 a $45 \%$ na estação chuvosa e de 0 a $20 \%$ na estação seca. Em termos sazonais, a cobertura de nuvens e precipitação é menor em julho e agosto durante o período central da estação seca e a máxima em fevereiro e março, na estação chuvosa. No caso da variabilidade interanual, a cobertura de nuvens média mensal em 2015 foi reduzida em alguns meses secos, como pode ser observado na Fig. 2. Atribui-se este fato a ocorrência do evento EN, nos quais as atividades de convecção, formação de nuvens e presença de chuva é reduzida na Amazônia Central (Fisch et al., 1998). Em um estudo feito para nuvens altas na Amazônia Central, Alves et al. (2007) observaram que as oscilações interanuais associadas aos fenômenos EN/LN contribuem fortemente para a variabilidade da cobertura de nuvens.

\subsection{Radiação solar}

\subsubsection{Ciclos sazonal e interanual}

$\mathrm{O}$ valor médio mensal da integral diária de todo o período de estudo é apresentada na Fig. 3, para todas componentes da irradiância solar. Analisando-se estas informações para a escala de tempo sazonal, observou-se que os valores da irradiância solar global e direta assemelharam-se em comportamento, quanto aos períodos de seus valores máximo e mínimos que ocorrem ao longo do ano. Os valores da irradiância solar global apresentados seguem a climatologia da região, com os maiores valores da ordem de $20 \mathrm{MJ} \mathrm{m}^{-2}$ dia $^{-1}$ durante a estação seca e os menores valores da ordem de $15 \mathrm{MJ} \mathrm{m}^{-2}$ dia $^{-1}$ na estação chuvosa. Estes resultados estão próximos daqueles encontrados por Salati
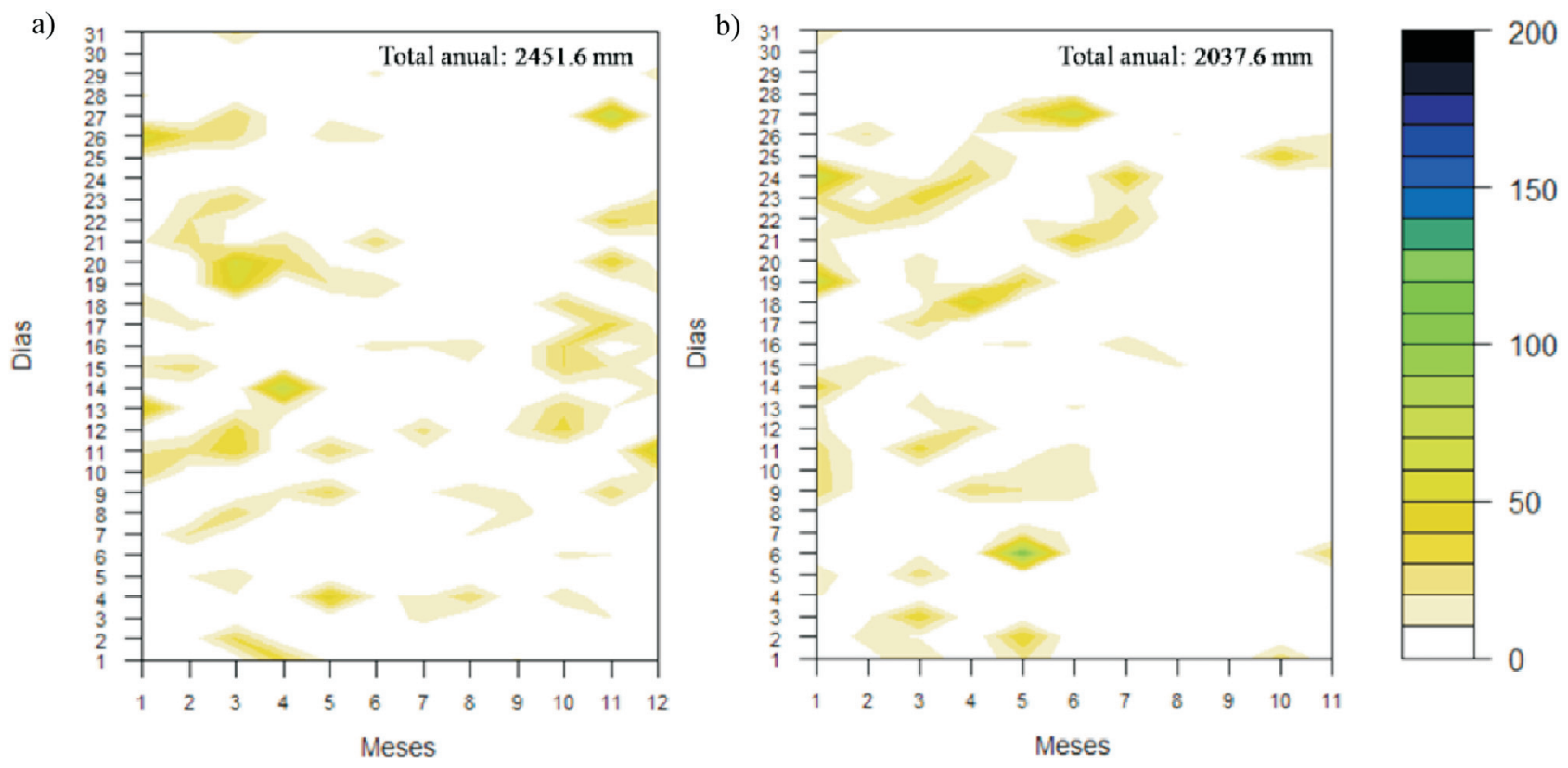

Figura 1 - Ciclo anual da precipitação diária (mm/dia): (a) 2014 e (b) 2015. 


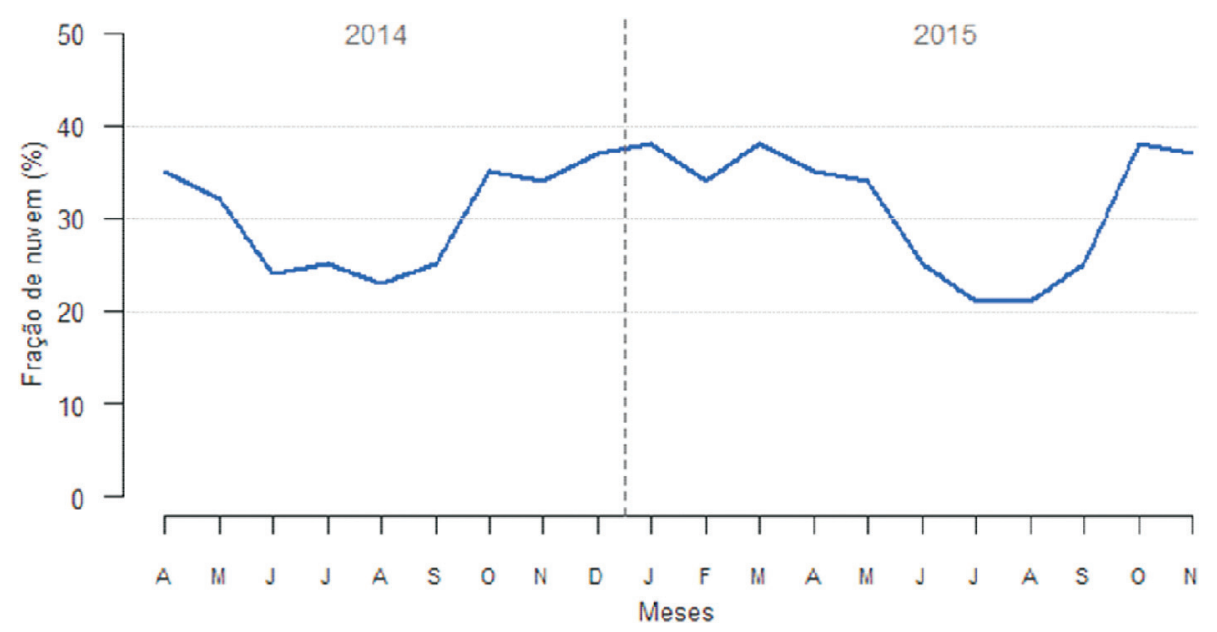

Figura 2 - Ciclo sazonal da fração de cobertura de nuvem de abril de 2014 a novembro de 2015.

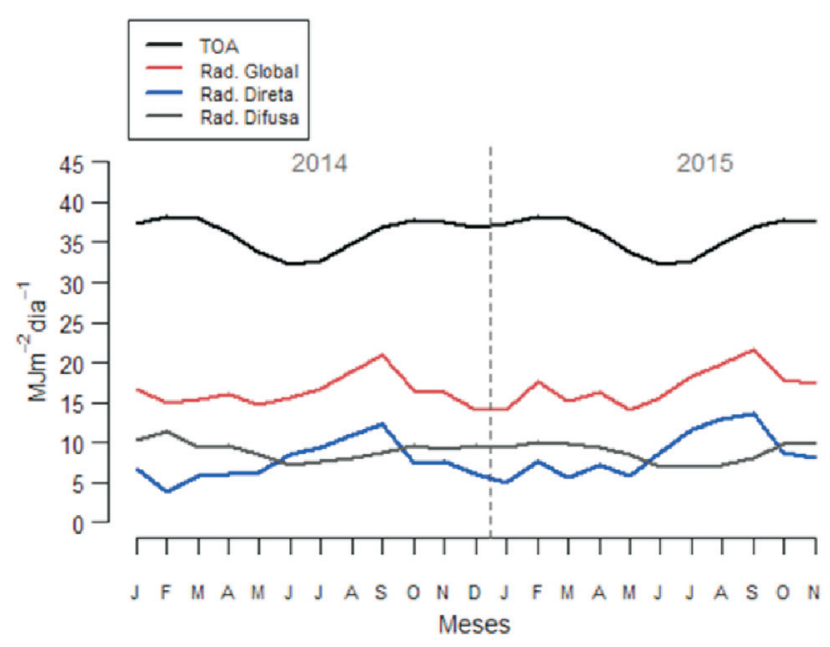

Figura 3 - Ciclo sazonal do valor integral diário médio da irradiância solar no topo da atmosfera, global, direta e difusa, de janeiro de 2014 a novembro de 2015 .

e Marques (1984), que obtiveram, para a cidade de Manaus-AM, valores médios variando entre 16 a $18 \mathrm{MJ} \mathrm{m}^{-2}$ $\mathrm{dia}^{-1}$, com os valores máximos ocorrendo em setembro/outubro e os valores mínimos em dezembro/fevereiro. A irradiância solar no topo da atmosfera (TOA) teve o seu valor máximo em fevereiro $\left(38,2 \mathrm{MJ} \mathrm{m}^{-2} \mathrm{dia}^{-1}\right)$ e o seu valor mínimo em julho (32,3 $\mathrm{MJm}^{-2} \mathrm{dia}^{-1}$ ), sendo isto associado ao o movimento de translação da Terra com relação ao Sol. A irradiância solar direta apresentou seus valores máximos e mínimos nos mesmos meses que a irradiância solar global, porém em menor magnitude. Os valores máximos ocorreram no período seco (da ordem de $12 \mathrm{MJ} \mathrm{m}^{-2} \mathrm{dia}^{-1}$ ) e os valores mínimos no período chuvoso (da ordem de $5 \mathrm{MJ} \mathrm{m}^{-2} \mathrm{dia}^{-1}$ ), devido a menor ou maior cobertura de nuvens, respectivamente.

Por outro lado, a irradiância solar difusa teve um comportamento com pouca variabilidade, se comparados com as demais componentes, apresentando uma amplitude de $4 \mathrm{MJm}^{-2}$ dia $^{-1}$ entre os valores observados nas estações seca e chuvosa. Os maiores valores (tipicamente de $11 \mathrm{MJm}^{-2} \mathrm{dia}^{-1}$ ) ocorrendo na estação chuvosa (devido a maior presença de nebulosidade) e os menores (tipicamente de $7 \mathrm{MJm}^{-2}$ dia $^{-1}$ ) no período seco (devido a menor presença de nuvens). A irradiância solar difusa foi superior ao valor da irradiância solar direta no período chuvoso, ocorrendo o contrário no período seco.

No caso da análise interanual, os valores da irradiância solar global e direta foram superiores no período seco de 2015 se comparados ao mesmo período de 2014, pois houve uma menor cobertura de nuvens, característico dos anos do evento EN. A irradiância solar difusa também foi superior no período seco de 2015 se comparado ao mesmo período de 2014.

Visando analisar com mais detalhes a variabilidade temporal das irradiâncias solar global, difusa e direta, os seus valores integrados diários médios mensais e respectivos desvios padrões são apresentados, de forma separada, na Fig. 4. Da irradiância solar global, Fig. 4a, observou-se que esta variou de 14 a $21 \mathrm{MJm}^{-2} \mathrm{dia}^{-1}$, onde os maiores valores ocorreram em setembro e os mínimos em maio, nos dois anos analisados (2014 e 2015). Quanto a sua variabilidade, representado pelo desvio padrão mensal, observou-se que os menores valores ocorrem em meses secos, especialmente setembro, em torno de $2,3 \mathrm{MJm}^{-2} \mathrm{dia}^{-1}$ (correspondente a $11 \%$ sobre o valor médio), devido a menor quantidade de cobertura de nuvens. De janeiro a agosto, nos dois anos (2014 e 2015), as variabilidades foram de 3,2 a $5,5 \mathrm{MJ} \mathrm{m}^{-2} \mathrm{dia}^{-1}$, sendo estes valores maiores e decorrentes da presença de nuvens e chuva.

Com relação aos valores analisados de irradiância solar difusa (Fig. 4b), observou-se que estes apresentaram a menor variabilidade das três componentes, entre 1 e $2 \mathrm{MJm}^{-2} \mathrm{dia}^{-1}$ (correspondente de 5 a $10 \%$ dos valores médios) ao longo dos 23 meses abordados. A irradiância difusa apresentou maiores valores de espalhamento no ano de 2015 em comparação ao ano de 2014, devido ao maior 

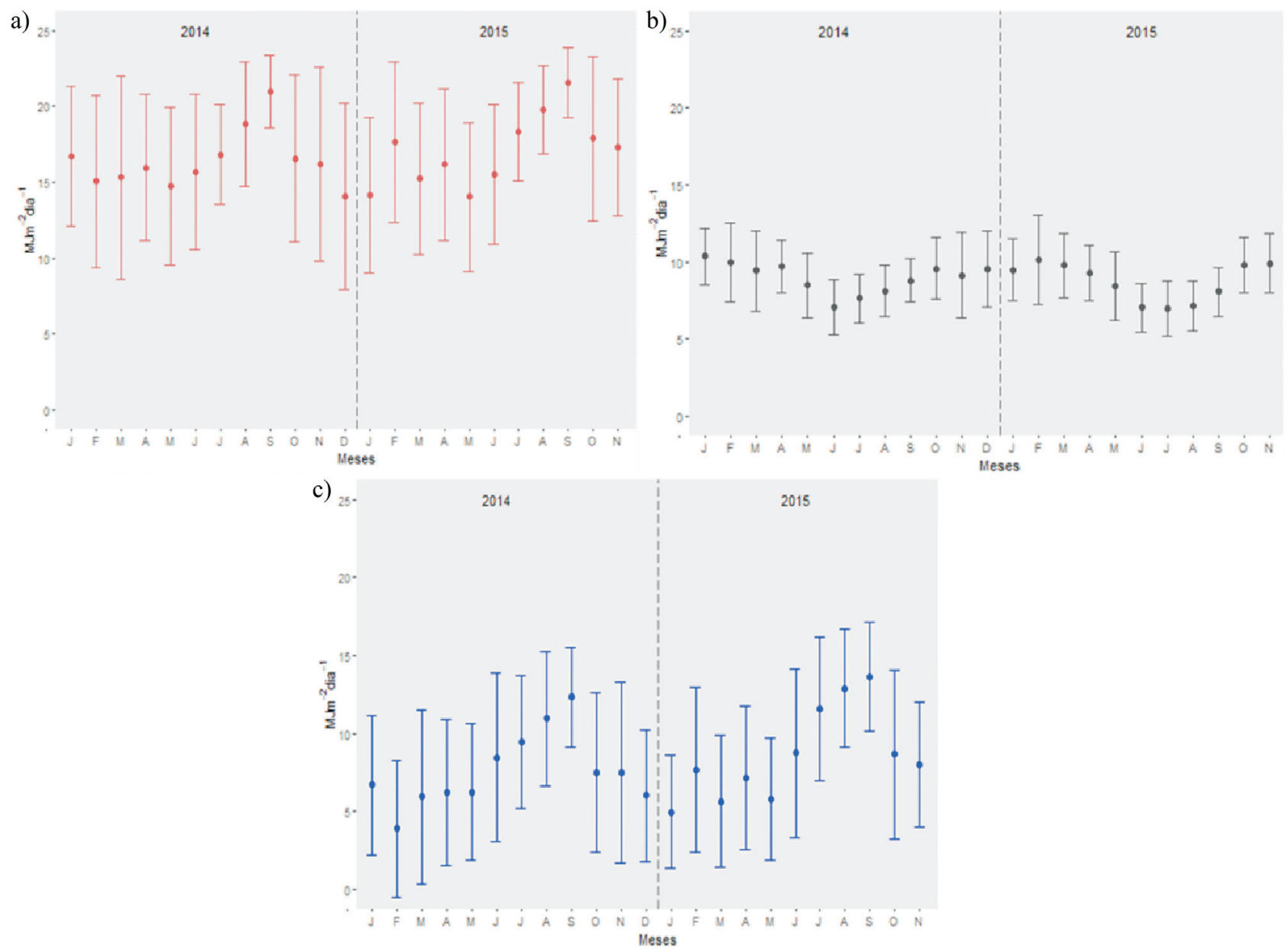

Figura 4 - Ciclo anual da integral diária (valor médio e desvio padrão associado) da irradiância solar (a) global, (b)difusa e (c) direta de Janeiro de 2014 a Novembro de 2015.

número de queimadas e concentração de aerossóis (seção 3.3). Na revisão de literatura, feita até o presente momento, não foram encontrados valores de referências do valor integral diário da irradiância solar difusa para a região. Apesar deste fato, uma série de estudos vem sendo realizada no sentido de compreender a interferência do espalhamento da radiação solar por aerossóis nas componentes da irradiância solar, principalmente relativo ao incremento da porção difusa Por exemplo, Yamasoe et al. (2006) observou significante redução da irradiância fotossínteticamente ativa (PAR) no topo do dossel devido a camada de partículas de fumaça oriundo de queimadas, afetando os fluxos turbulentos de calor sensível e latente, como consequiência do aumento da irradiância solar difusa devido ao espalhamento pelas partículas de aerossóis. Dougthy et al. (2010) mostrou que partículas de aerossóis podem afetar o ecossistema diretamente através da alteração no espalhamento da luz solar, com o decaimento da irradiância solar global à superfície e incremento da irradiância solar difusa. Cirino et al. (2014) examinou os efeitos das mudanças no balanço de irradiância sobre áreas de floresta tropical devido presença de partículas de aerossol e nuvens nas porções sudoeste (Ji-Paraná-RO) e central (Manaus-AM) da Amazônia. Obteve que nuvens e aerossóis provenientes da queima de biomassa causam redução de até $35 \%$ na quantidade de irradiância total de PAR e também um aumento de até $50 \%$ na fração de irradiância PAR difusa, que é utilizado de forma mais eficiente pelo processo de fotossíntese da floresta. Rap et al. (2015) observou que na presença de nuvens finas ou aerossol, a irradiância solar direta é reduzida devido ao espalhamento da luz solar, enquanto a irradiância solar difusa é incrementada. Entretanto, estes estudos utilizaram conjunto de dados de curta duração (de dias ou apenas algumas semanas).

Os valores médios mensais da irradiância solar direta (Fig. 4c) apresentaram as maiores variabilidades das três componentes (tipicamente da ordem de 3,2 a 4,6 $\mathrm{MJ} \mathrm{m}^{-2}$ $\operatorname{dia}^{-1}$ ) em todo o período. Os valores médios de irradiância solar direta variaram de 3 a $13 \mathrm{MJm}^{-2} \mathrm{dia}^{-1}$, com os máximos no período seco e os mínimos no período chuvoso, devido a presença de nebulosidade. Na revisão de literatura, feita até o momento, também não foram encontrados valores referenciais da integral diária da irradiância solar direta. Isto ocorre devido a dificuldade em utilizar instru- 

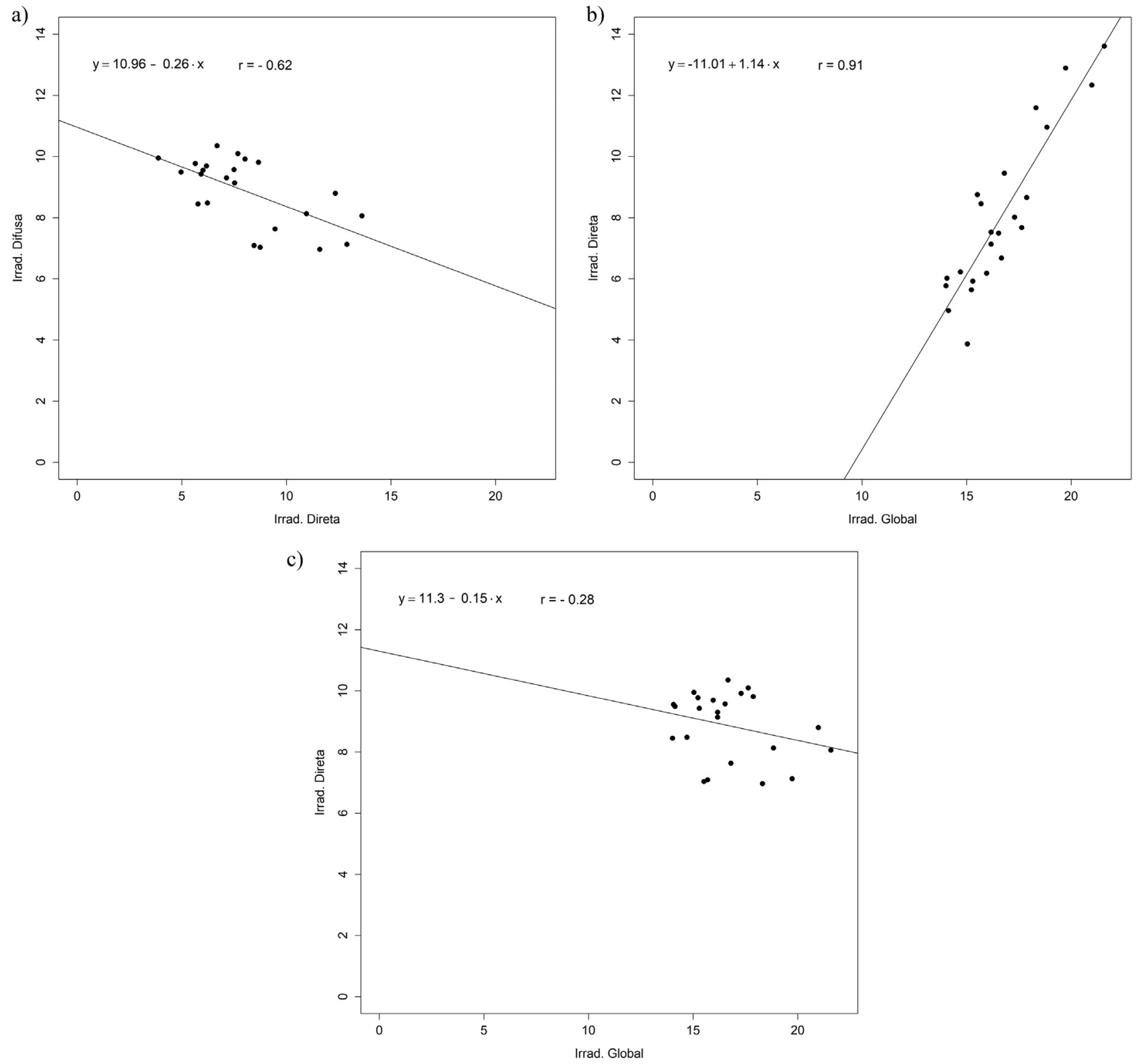

Figura 5 - Regressão linear da irradiância solar, em Wm²: a) direta em função da difusa, b) direta em função da global e c) difusa em função da global.

mentos de medição direta (piroheliometro). Um dos poucos trabalhos na Amazônia central que descrevem esta componente foi o de Almeida et al. (1979), mas que considerou apenas 1 dia desta informação para Manaus (AM).

Com o objetivo de analisar as interrelações e dependências entre as componentes de irradiância solar, determinou-se regressões lineares entre os valores médios mensais das três componentes (Fig. 5). A melhor relação encontrada foi entre as irradiâncias solar global e direta, com um coeficiente de correlação de 0,91 , mostrando que a medida da irradiância solar global (que é mais usual e utiliza um piranômetro) pode ser um bom estimador da irradiância solar direta, que necessita de um instrumento (piroheliometro) mais caro e de difícil manutenção. As relações que envolvem a irradiância solar difusa mostraram que esta foi inversamente proporcional as irradiâncias solar global ou direta, ou seja, aumentando a cobertura de nuvens, as irradiâncias solar global e direta diminuem, pois uma maior parte é refletida pelas nuvens para o espaço. Apesar do aumento da porção difusa provocado pela cobertura de nuvens, a redução nas porções de irradiância solar global e direta é maior, induzindo esta dependência inversamente proporcional. Butt et al. (2010) analisaram, também através de um modelo de regressão linear, o desempenho na previsão da radiação solar difusa em função da fração de cobertura de nuvens, com baixa representatividade no período seco devido à presença de aerossóis na atmosfera. Estas análises foram feitas para uma de floresta 

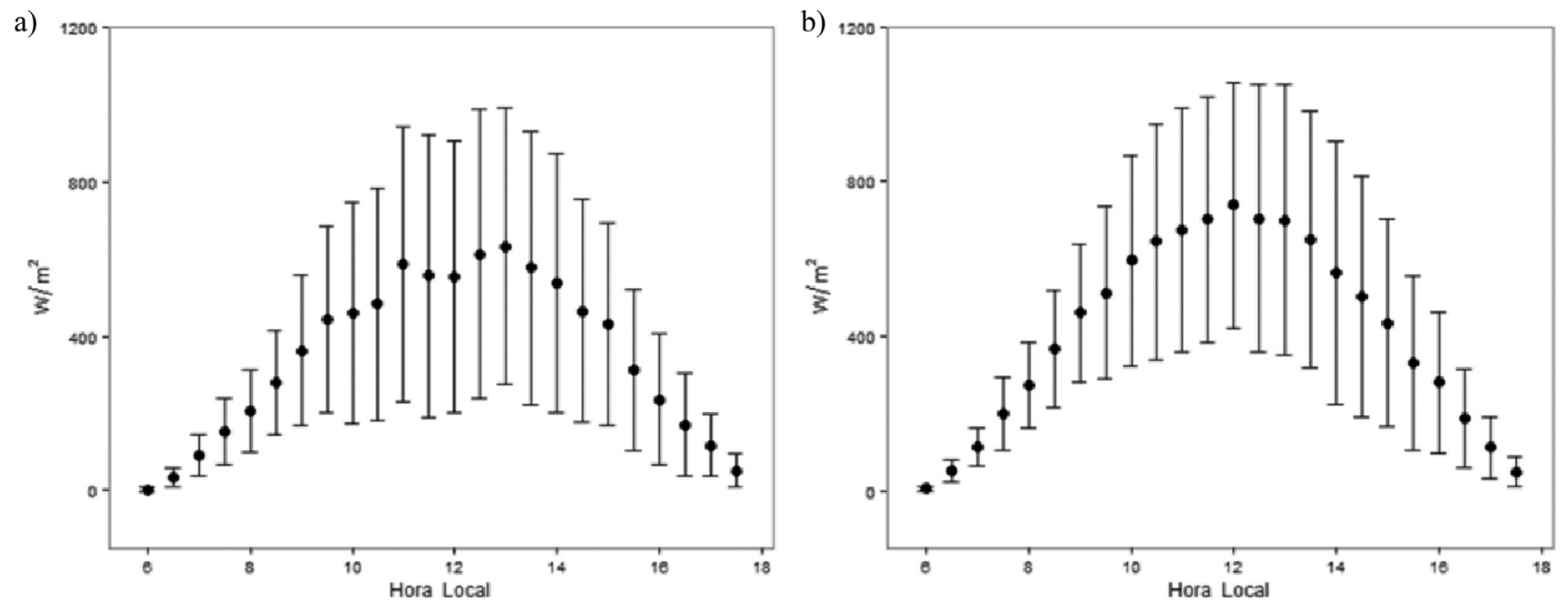

Figura 6 - Média mensal horária e desvio padrão do ciclo diário da irradiância solar global de fevereiro de: (a) 2014 e (b) 2015.

a)

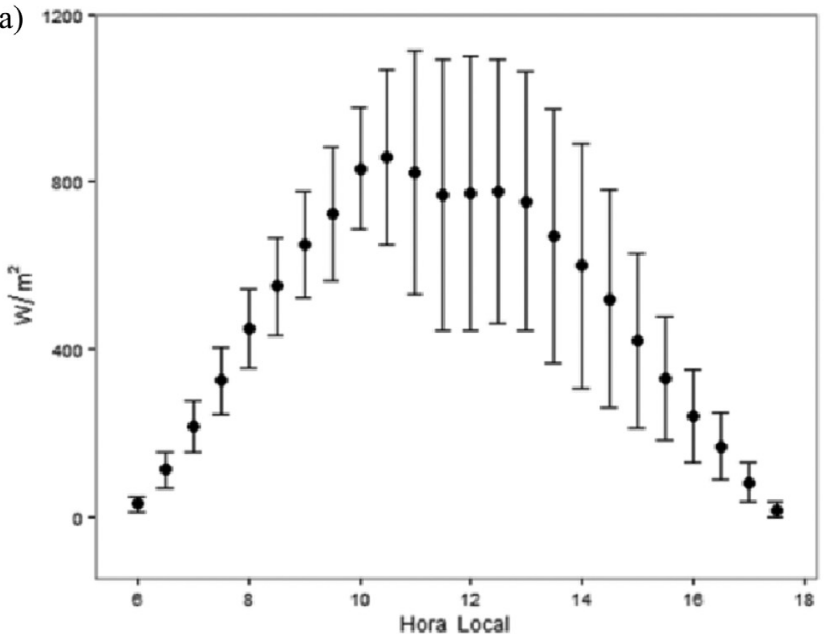

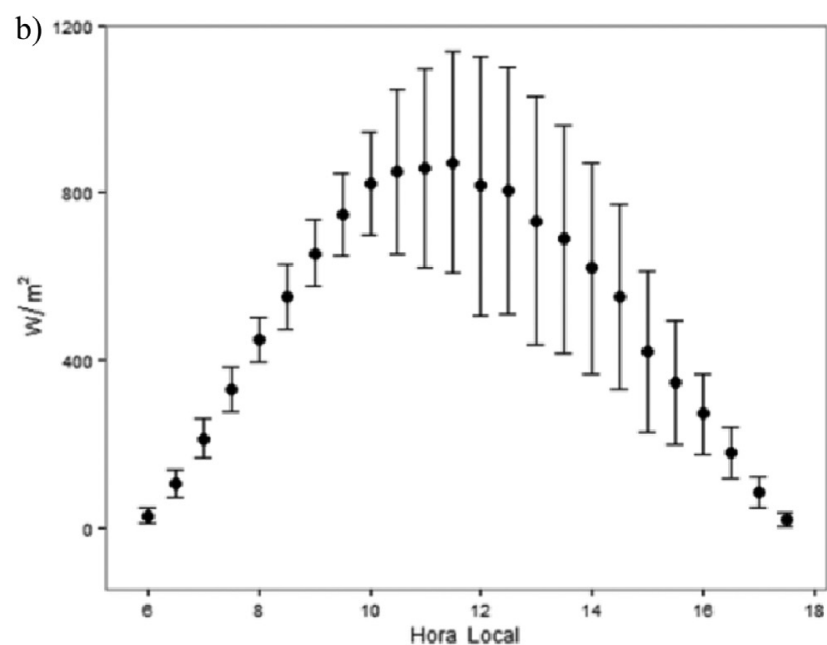

Figura 7 - Média mensal horária e desvio padrão do ciclo diário da irradiância solar global de setembro de: (a) 2014 e (b) 2015.

tropical na Amazônia ocidental, condições similares as obtidas neste trabalho.

\subsubsection{Ciclo diário}

Foram escolhidos um mês representativo da estação chuvosa (fevereiro) e outro da estação seca (setembro) para os dois anos em análise (2014 e 2015). Os demais meses dos anos de 2014 e 2015 podem ser vistos em Apêndices B, $\mathrm{C}$ e D de Macedo (2016). Na sequência são apresentadas os valores médios mensais horários do ciclo diário da irradiância solar global e seus desvios padrões (Figs. 6 e 7).

No mês de fevereiro (Fig. 6) o valor médio máximo fica em torno de torno de $680 \mathrm{Wm}^{-2}$, com desvios padrões máximos em torno de $360 \mathrm{Wm}^{-2}$ e estes ocorreram entre 10 e 15 h, que é o horário da máxima convecção. Em setembro (Fig. 7), estes valores são ainda maiores (da ordem de $800 \mathrm{Wm}^{-2}$ ), pois neste período a atmosfera tende a ter uma menor presença de nuvens e céu mais claro, permitido que maior fluxo de irradiância solar global atinja a superfície.
Observou-se que os horários de máximo desvio padrão no período chuvoso, se distribuíram, de maneira geral, homogeneamente, centrando-se às entre 10 e 15 horas. No período seco, os horários de máximo desvio padrão ocorrem mais próximos do meio dia, devido a máxima convecção no período seco ocorrer mais tarde. Isto fica claro pelos altos valores médios da irradiância solar, bem como pela pequena variabilidade dos dados no período da manhã, que aumentam ao longo do dia em função da intensificação da convecção e aumento de nebulosidade. Os valores médios mensais em fevereiro foram de 363 e $420 \mathrm{Wm}^{-2}$ para os anos de 2014 e 2015, respectivamente, sendo que estes valores aumentaram para 506 e $521 \mathrm{Wm}^{-2}$ em setembro. Em relação aos valores encontrados na literatura, os valores mínimos, referentes ao período chuvoso estão um pouco superiores aqueles apresentados por Vila Nova et al. (1978), que encontraram o valor médio de $325 \mathrm{Wm}^{-2}$, de janeiro-março (período chuvoso) para Manaus-AM. Recen- 

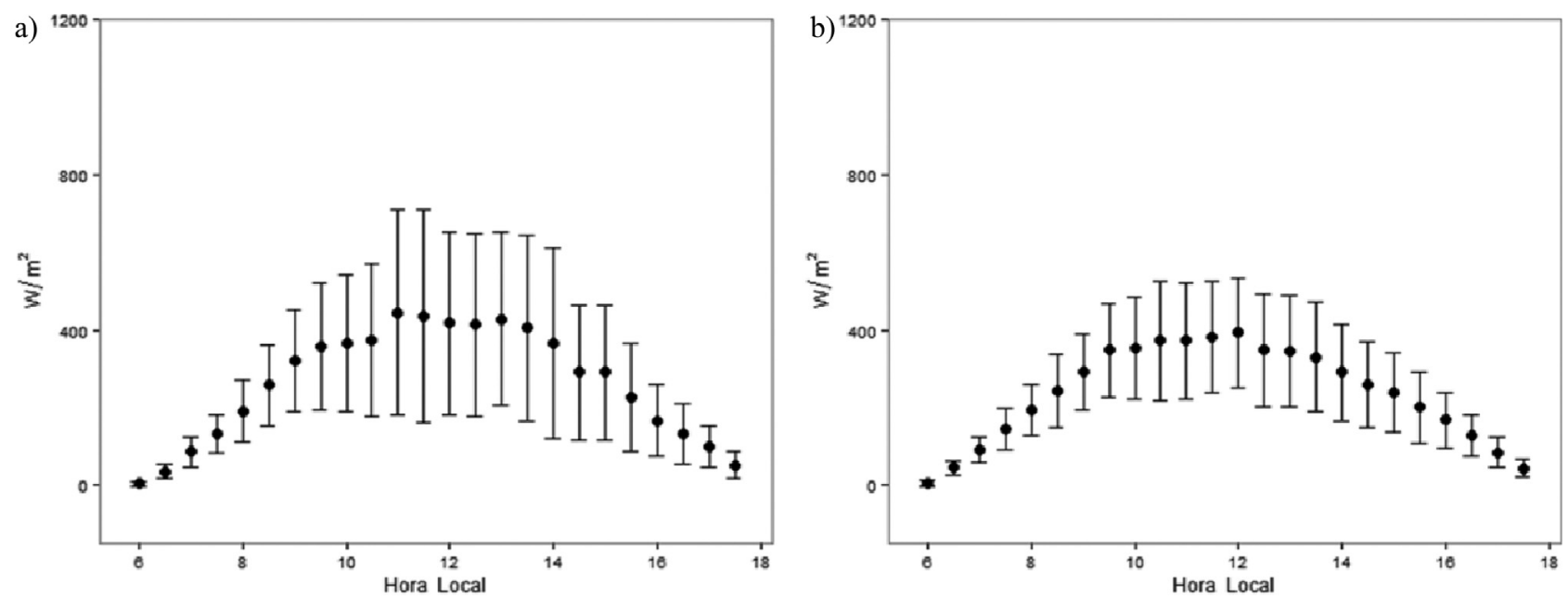

Figura 8 - Média mensal horária e desvio padrão do ciclo diário da irradiância solar difusa de fevereiro de: (a) 2014 e (b) 2015.
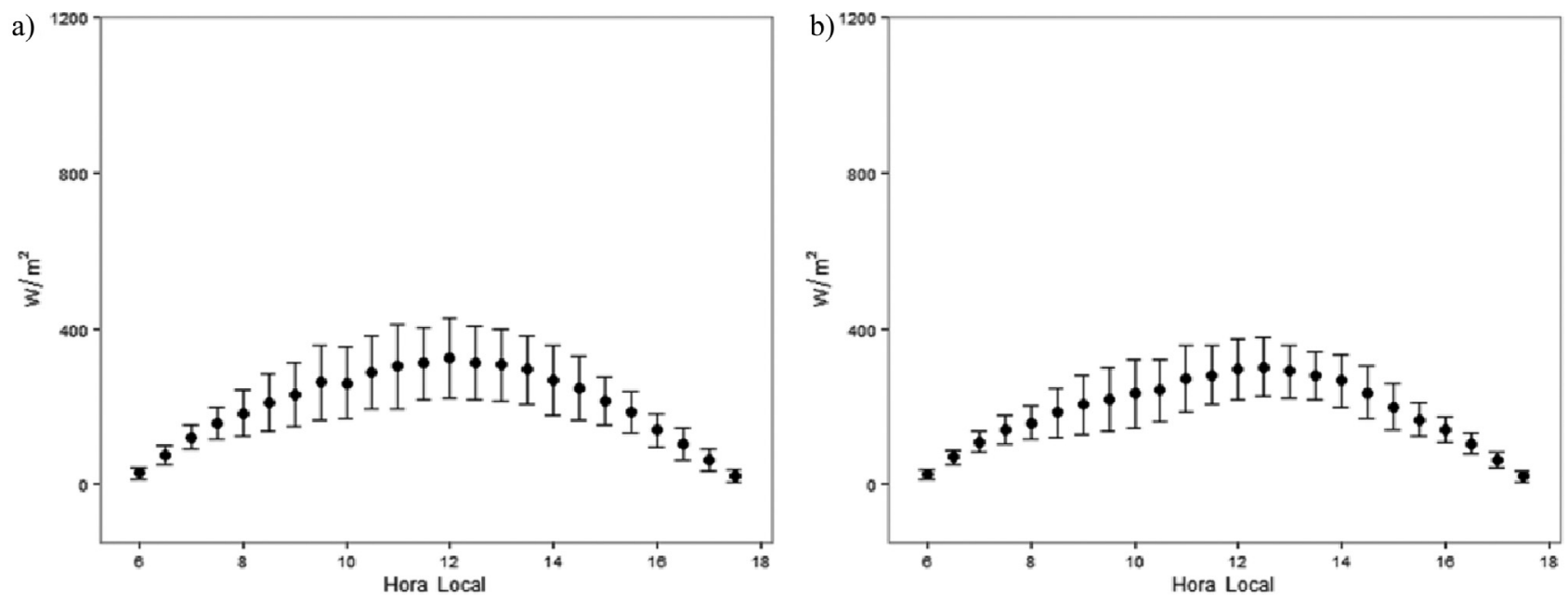

Figura 9 - Média mensal horária e desvio padrão do ciclo diário da irradiância solar difusa de setembro de: (a) 2014 e (b) 2015.

temente, Pavão et al. (2014) mostraram que, para uma área de floresta nativa em Humaitá-AM, os valores médios mensais de irradiância solar global medidos em meses chuvosos estão entre 314 e $334 \mathrm{Wm}^{-2}$. Os resultados obtidos em setembro também se assemelham àqueles encontrados por Villa Nova et al. (1978) que encontraram maiores valores médios diários da irradiância solar global entre 513 e 541,8 $\mathrm{Wm}^{-2}$ em agosto-setembro (período seco).

As Figs. 8 e 9 mostram os valores médios da irradiância solar difusa e desvios padrões do mês de fevereiro e setembro de 2014 e 2015, respectivamente. Em fevereiro (Fig. 8), os máximos valores médios foram $445 \mathrm{Wm}^{-2} \mathrm{em}$ 2014 e $392 \mathrm{Wm}^{-2}$ em 2015. Os valores máximos de desvio padrão ficaram em torno de 270 e $150 \mathrm{Wm}^{-2}$ para os anos de 2014 e 2015, respectivamente. Estes resultados concordam com a menor nebulosidade em fevereiro de 2015, que diminuiu a fração difusa da irradiância solar. Em setembro (Fig. 9), os valores médios máximos são menores do que em fevereiro. Isto ocorre pois, neste período, a atmosfera tende a ter uma menor presença de nuvens e céu mais claro, permitindo o maior fluxo de irradiância solar global e direta a superfície. Os valores máximos foram em torno de 320 $\mathrm{Wm}^{-2}$ e os desvios padrões máximos foram de $100 \mathrm{Wm}^{-2}$. Em setembro a irradiância solar difusa média foi superior em 2014 em relação a 2015 para todo o ciclo diário devido ainfluência do evento EN (menor valores de nebulosidade e chuva na região), conforme já discutido (Macedo, 2016).

Os valores médios mensais da irradiância solar difusa ao longo dos anos de 2014 e 2015 estiveram entre 509 e $520 \mathrm{Wm}^{-2}$ no mês de setembro (período seco) e os mínimos próximos de 350 e $400 \mathrm{Wm}^{-2}$ de janeiro a junho (período chuvoso). Observou-se comportamento pouco variável da irradiância solar difusa média em relação à sazonalidade, ao longo do período estudado. Os valores máximos da variabilidade ocorreram em fevereiro (no período chuvoso) próximos de $270 \mathrm{Wm}^{-2}$, com os valores mínimos em torno de $200 \mathrm{Wm}^{-2}$ de junho a agosto (período seco). 

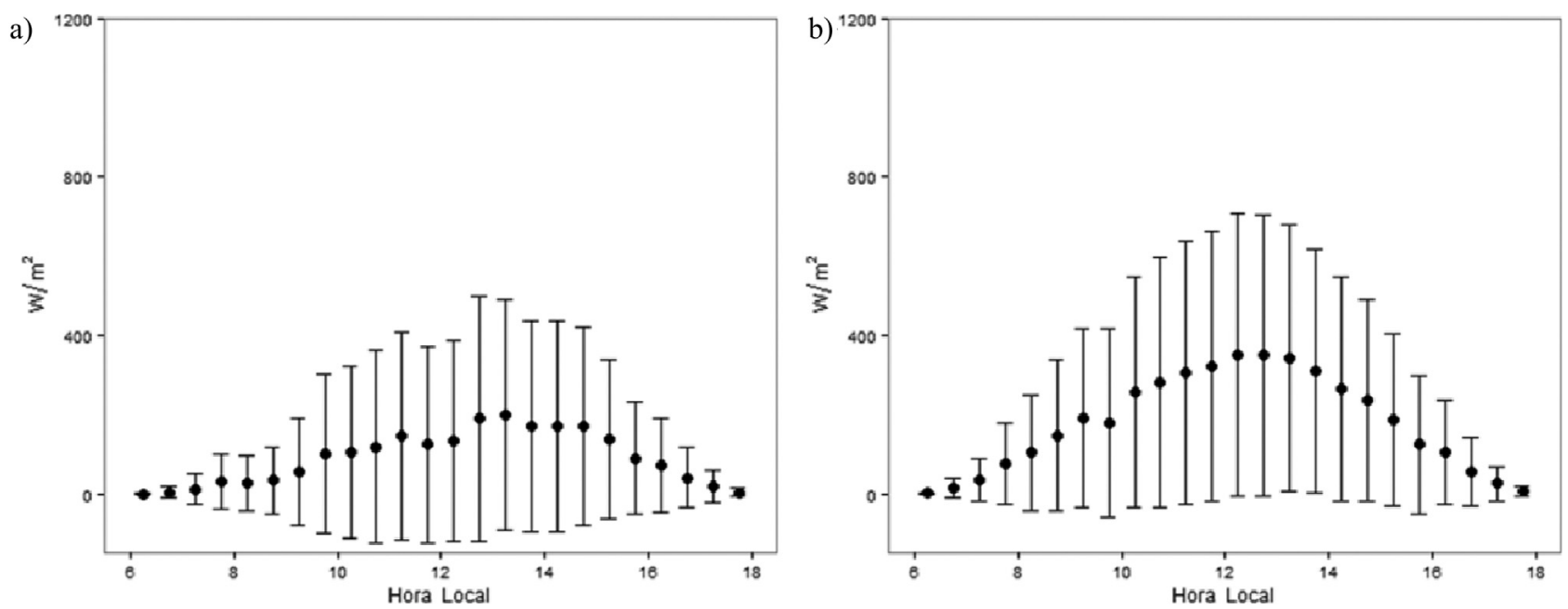

Figura 10 - Média mensal horária e desvio padrão do ciclo diário da irradiância solar direta de fevereiro de: (a) 2014 e (b) 2015.
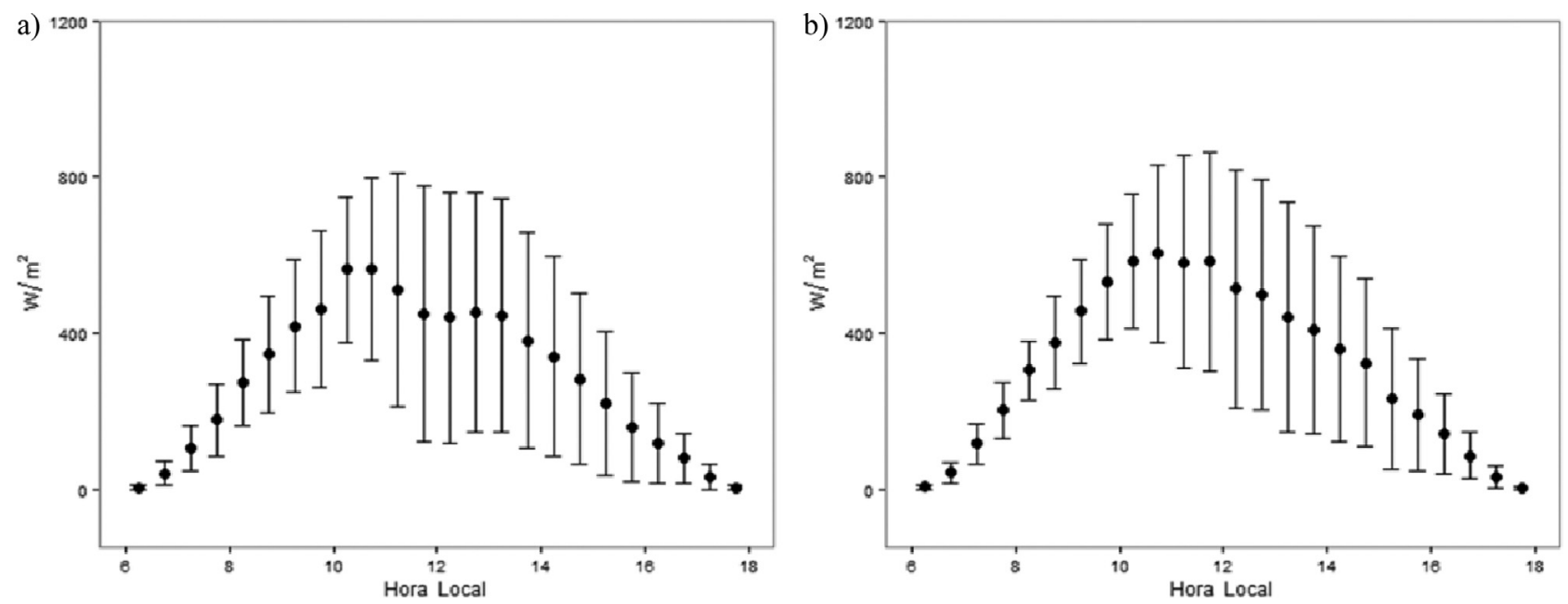

Figura 11 - Média mensal horária e desvio padrão do ciclo diário da irradiância solar direta de setembro de: (a) 2014 e (b) 2015.

As Figs. 10 e 11 mostram os valores médios e desvios padrões da irradiâncias solar direta do mês de fevereiro e setembro de 2014 e 2015, respectivamente. Em fevereiro (Fig. 10), os máximos valores médios foram $199 \mathrm{Wm}^{-2} \mathrm{em}$ 2014 e $350 \mathrm{Wm}^{-2}$ em 2015, sendo que em 2015 as médias foram superiores em todo o ciclo diário. Os valores máximos de desvio padrão ficaram em torno de $309 \mathrm{Wm}^{-2}$ em 2014 e $355 \mathrm{Wm}^{-2}$ em 2015. Em setembro (Fig. 11), os valores médios máximos são maiores do que em fevereiro, pois, neste período, a atmosfera tende a ter uma menor presença de nuvens e céu mais claro, permitindo o maior fluxo de irradiância solardireta a superfície, assim como se observou para a irradiância solar global. Os valores máximos foram em torno de $563 \mathrm{Wm}^{-2}$ em 2014 e $604 \mathrm{Wm}^{-2} \mathrm{em}$ 2015 e os desvios padrões máximos foram de $329 \mathrm{Wm}^{-2} \mathrm{em}$ 2014 e $305 \mathrm{Wm}^{-2}$ em 2015.

Observou-se também que as os valores de variabilidade máximos de irradiância solar direta ocorreram nos meses do período seco e foram em torno de $285 \mathrm{Wm}^{-2}$ no ano de 2014 (setembro) e $353 \mathrm{Wm}^{-2}$ em 2015 (agosto). Nos meses considerados chuvosos, de janeiro a abril, a irradiância solar direta apresentou valores menores de variabilidade, entre 115 e $178 \mathrm{Wm}^{-2}$.

Observou-se, para as componentes global e direta da irradiância solar que os valores de desvio padrão distribuem-se de maneira mais uniformes na estação chuvosa (Figs. 8a e 12a), em comparação ao período seco (Figs. 9b e 13b), quando os máximos de desvio padrão aumentaram a partir do final da manhã. Isto se deve a formação de nuvens ocorrer de maneira mais intensa, no período seco, a partir do final da manhã. Durieux et al. (2003) mostraram, para o estudo em uma área desflorestada da Amazônia, que, durante a estação seca, ocorre a presença de nuvens baixas a partir do início da tarde. Machado et al. (2004) mostraram que mudanças na circulação de larga escala ou na superfície, que ocorre na estação seca e chuvosa, influenciam a convecção e fração de nuvens da região da floresta equatorial. 

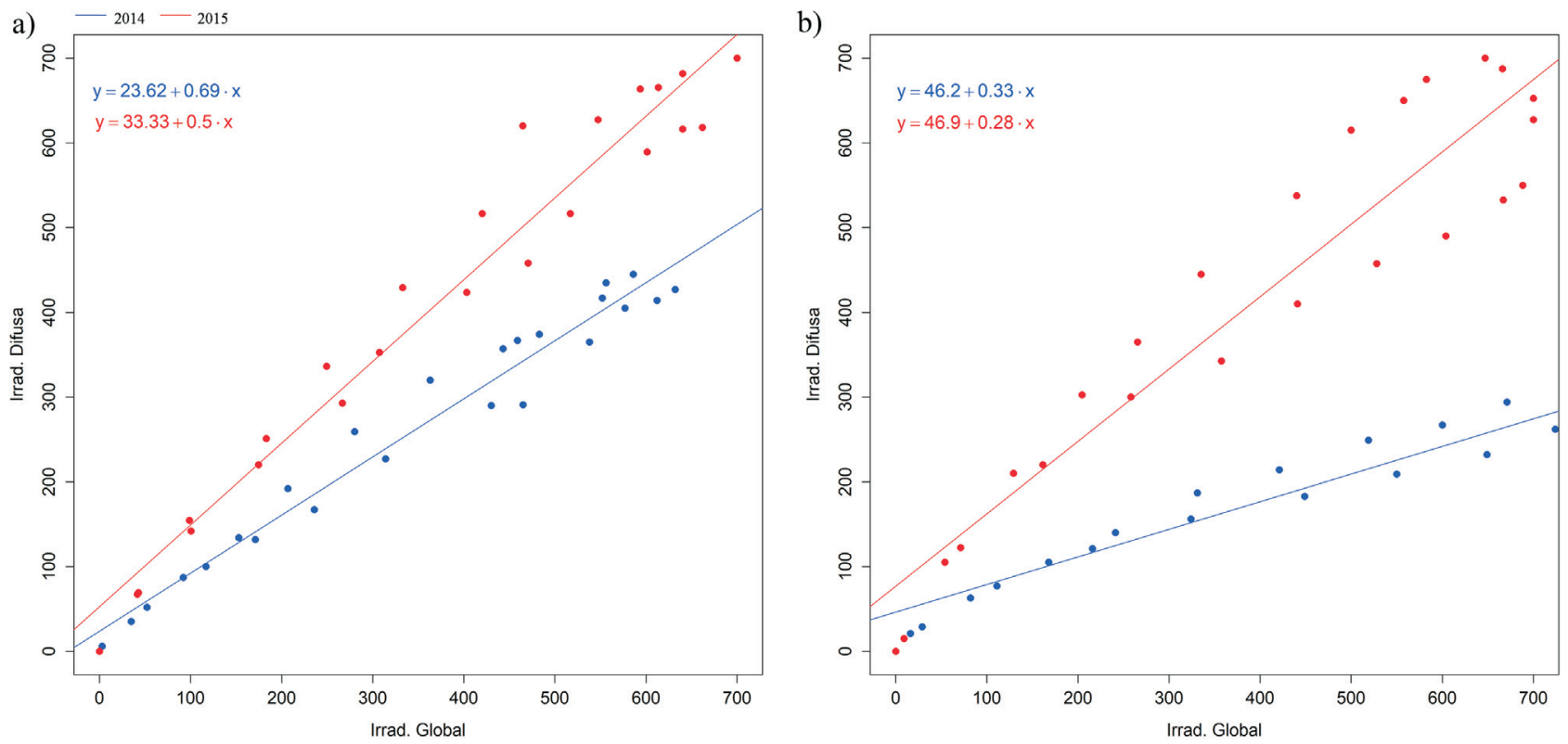

Figura 12 - Regressão linear entre os valores médios horários das irradiâncias solar global e difusa, em $\mathrm{Wm}^{-2}$, nos meses de: (a) fevereiro e (b) setembro.
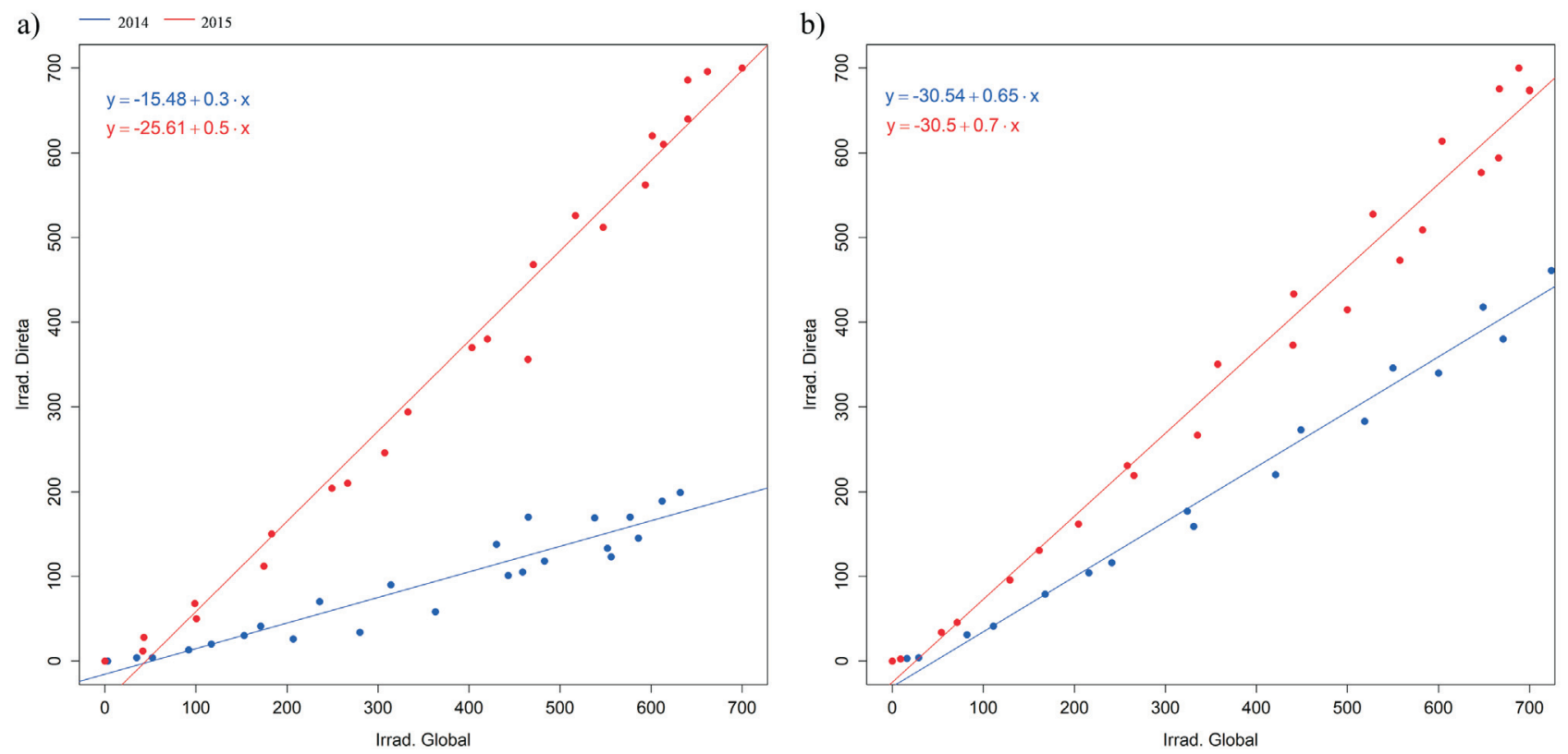

Figura 13 - Regressão linear entre os valores médios horários das irradiâncias solar global e direta, em $\mathrm{Wm}^{-2}$, nos meses de: (a) fevereiro e (b) setembro.

As Figs. 12, 13 e 14 mostram as regressões lineares dos valores médios horários de irradiância solar em dois meses representativos das estações chuvosa (fevereiro) e seca (setembro) nos anos de 2014 e 2015. Como era de se esperar, dada as condições de menor cobertura de nuvens no ano de 2015 (seção 3.1), as relações entre as 3 componentes da irradiância solar foram diferentes. Por exemplo, a menor cobertura de nuvens no período chuvoso em 2015 provocou uma relação maior entre as irradiâncias solar direta e global (Fig. 13a). Este mesmo fato, também induziu uma maior quantidade da componente difusa, pois nuvens esparsas aumentam a reflexão pelas nuvens
(Fig. 12a). A Fig. 14a sintetiza estas informações, pois mostra uma equipartição da energia entre as irradiâncias solar difusa e direta no ano de 2015, que não se observou no ano de 2014 (quando a maior cobertura de nuvens influenciou a quantidade de irradiância que atingiu a superfície). No caso do período seco, a influência das queimadas e aerossóis (seção 3.3) também pode ser observado: a irradiância solar difusa em 2015 foi maior do que em 2014, quer seja comparando-se com a irradiância solar global (Fig. 12b), quer seja pela componente direta (Fig. 13b). Na Fig. 14b, além da irradiância solar difusa ter sido maior em 2015 do que em 2014, devido ao espalhamento pelas partí- 

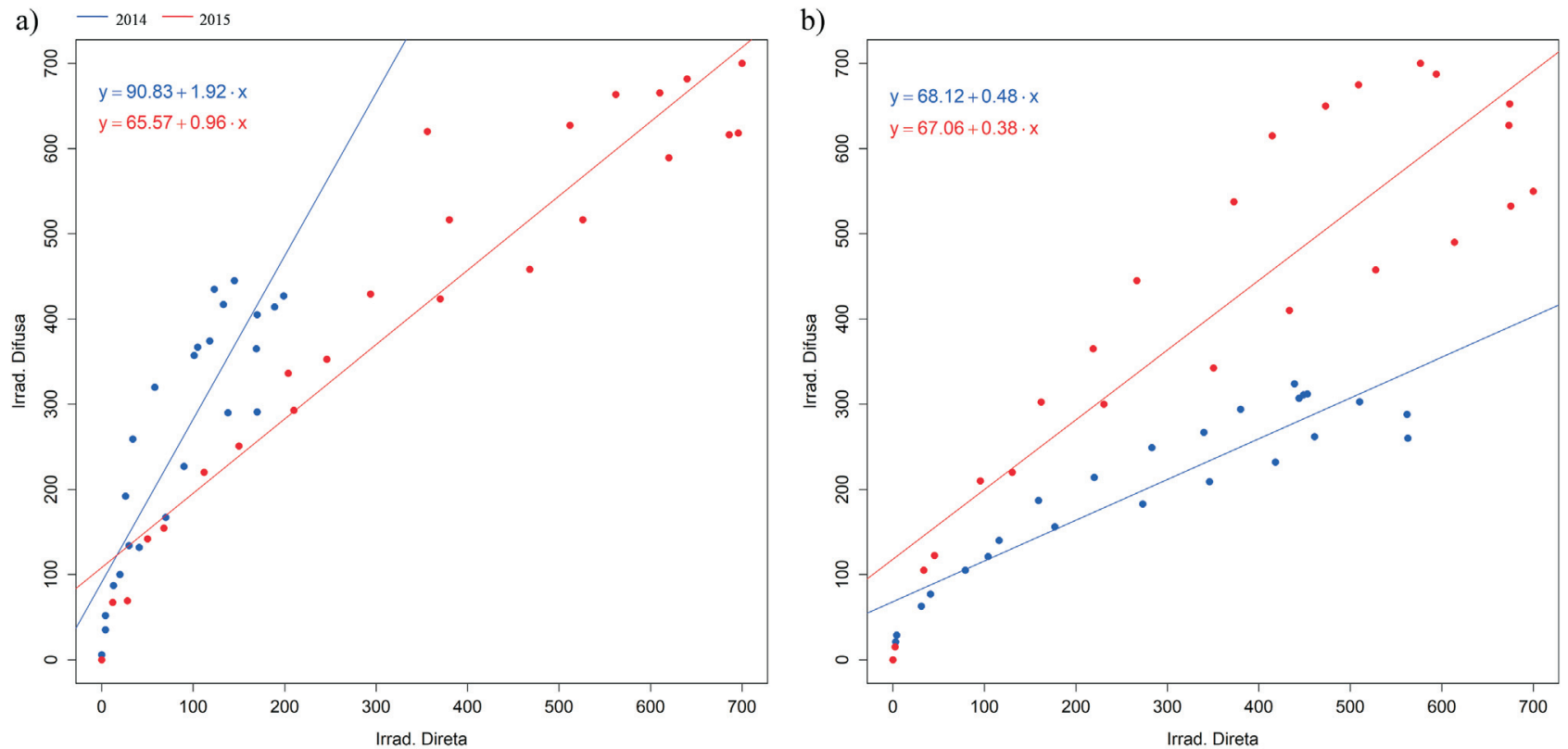

Figura 14 - Regressão linear entre os valores médios horários das irradiâncias solar direta e difusa, em Wm², nos meses de: (a) fevereiro e (b) setembro.

culas sólidas dos aerossóis, observa-se também o ciclo diurno da parte difusa no período da manhã (valores abaixo da reta 1:1) e da tarde (valores acima da reta 1:1).

\subsection{Estudo de caso: período seco de 2015}

No ano de 2015, a região da Amazônia Central (Manaus, AM) sofreu bastante com o período de seca, de agosto a novembro, sendo que as queimadas tornaram a região extremamente poluída, diminuindo a visibilidade e atrapalhando as atividades comuns da população. De modo geral, o mês de setembro apresenta o maior número de foco de queimadas na região, sendo que estes valores foram de 50 focos em 2014 e de 100 focos em 2015. Ressalta-se de que os valores totais anuais de 2015 foram $63 \%$ maior do que fora observado no ano de 2014, que era, até então, o maior valor obtido na determinação de focos de queimadas. Isto claramente mostra o efeito do evento EN, com a redução da precipitação, intensificação do período de seca e um aumento do número de queimadas na região. A região de Manaus apresentou vários problemas de redução de visibilidade, inclusive com o fechamento do aeroporto da cidade (Macedo, 2016). Os valores médios mensais do Aerosol Optical Depth (AOD), que é um indicativo da quantidade e da eficiência de extinção de irradiância solar pela matéria opticamente ativa em um dado comprimento de onda estão apresentados na Fig. 15 e mostraram, por exemplo, que o período final da estação seca de 2015 apresentou valores de AOD (entre 0,7 - 0,8 adimensional) quase que o dobro do valor observado em 2014 (tipicamente de 0,4). Estes valores obtidos estão dentro dos limites obtidos por Artaxo et al. (2013), que encontrou para o sítio de floresta tropical não perturbada T34 (100 km a nordeste do sítio T3), com dados da rede AERONET, valores de AOD variando de 0,1 a 1,2. Ainda nas cercanias da região de Manaus, Cirino et al. (2014) mostrou que para Balbina (280 km a nordeste do sítio T3), através de medições com o sensor MODIS (Moderate Resolution Imaging Spectroradiometer) a bordo dos satélites Terra e Aqua, que na estação chuvosa os valores de AOD eram em torno de 0,1 e aumentam, na estação seca, para valores de cerca de 1,5 , salientando que os dados do MODIS costumavam superestimar os dados da AERONET. Em síntese, a ocorrência de um período mais seco do que o normal (em função do evento $\mathrm{EN}$ ) provocou um maior número de foco de queimadas e, consequentemente, valores maiores de AOD. Estes efeitos foram sentidos nas medições de irradiância solar global, difusa e direta, como descrito nos itens 3.1 e 3.2 e apresentados na Fig. 16, para um período de 3 dias de forte influência dos aerossóis na região (16, 17 e 18/10/2015). Nestes 3 dias, total integrado da irradiância solar global reduziu-se de um valor de $20.4 \mathrm{MJm}^{-2} \mathrm{dia}^{-1}$ do dia $16 / 10$, para um valor de

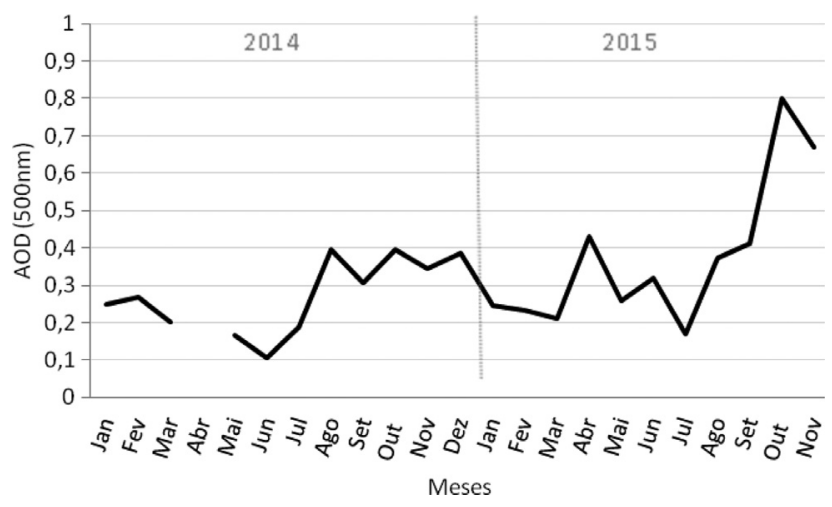

Figura 15 - Série temporal dos valores médios AOD entre janeiro de 2014 a novembro de 2015 . 
a)

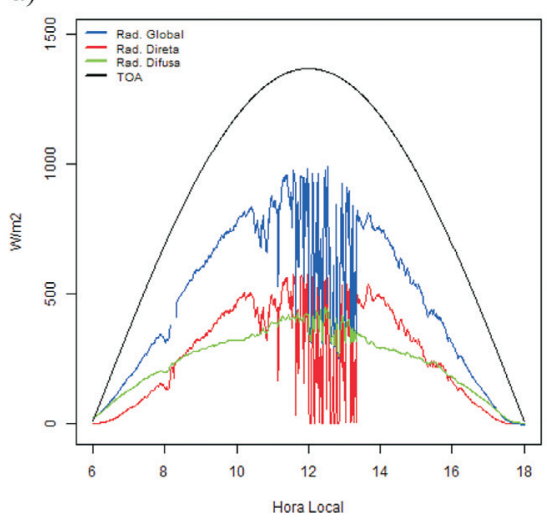

b)

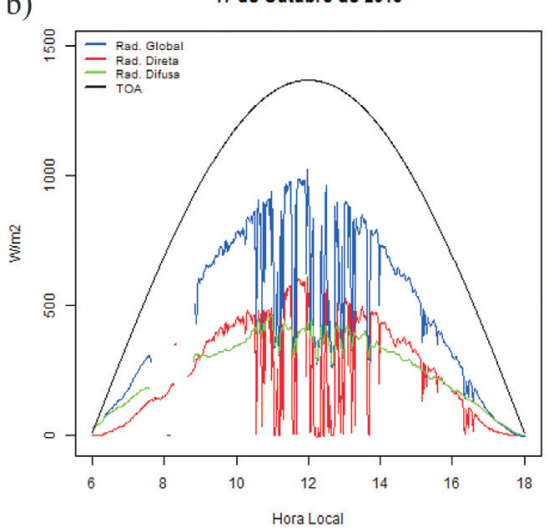

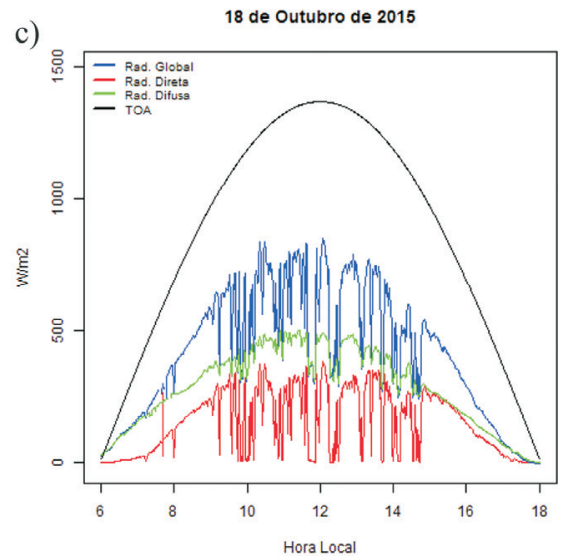

Figura 16 - Ciclo diário da irradiância solar TOA, global, direta e difusa nos dias: (a)16, (b) 17 e (c) 18 de Outubro de 2015.

17,6 $\mathrm{MJ} \mathrm{m}^{-2}$ dia $^{-1}$ no dia 18/10. A irradiância solar difusa aumentou sua contribuição de $50 \%$ no dia $16 / 10$ para $67 \%$ para o dia $18 / 10$, ao passo que a irradiância solar direta reduziu-se de $50 \%$ para $33 \%$ nestes mesmos dias.

\section{Conclusões}

Este trabalho realizou um estudo da variabilidade temporal das irradiâncias solar global, direta e difusa ao longo dos anos de 2014 e 2015, na região da Amazônia Central, durante o experimento GOAmazon 2014/15. De forma complementar, também foram analisados a cobertura de nuvens, precipitação e aerossóis.

Valores típicos das três componentes da irradiância solar global, direta e difusa foram determinadas para as escalas de tempo horária, sazonal e inter-anual. Para os valores horários, foram observados valores máximos de $800 \mathrm{Wm}^{-2}$ na estação seca e de $600 \mathrm{Wm}^{-2}$ para o período chuvoso. As medidas do desvio padrão da irradiância solar global no período seco mostra claramente o início da convecção, por volta das 10 horas. No caso da escala sazonal, os valores médios típicos para a irradiância solar global foi de 340-420 $\mathrm{Wm}^{-2}$ para a estação chuvosa e de 400$520 \mathrm{Wm}^{-2}$ para o período seco. No caso das irradiâncias solar difusa e direta, a contribuição difusa apresentou maiores valores $\left(\sim 240 \mathrm{Wm}^{-2}\right)$ do que a contribuição direta $\left(\sim 120 \mathrm{Wm}^{-2}\right)$ no período chuvoso, e o inverso na estação seca, com a contribuição direta $\left(\sim 260 \mathrm{Wm}^{-2}\right)$ maior do que a difusa $\left(\sim 200 \mathrm{Wm}^{-2}\right)$. Finalizando, ocorreu a presença do evento EN de 2015, que provocou uma menor quantidade de chuva, uma menor nebulosidade em ambos os períodos (chuvoso e seco) e uma maior quantidade de queimadas e de aerossóis, principalmente na estação seca. Esta situação impactou nas quantidades de irradiância solar global, direta e difusa, que foram maiores do que seus valores em 2014. As interrelações entre as 3 medidas também foram estudadas e observou-se que as irradiâncias solar global e direta estão diretamente relacionadas e com alto índice de correlação. Por outro lado, as interrelações entre as irradiâncias solar difusa e global ou direta, mostraram-se que ocorrem de forma inversa. Observou-se, de modo geral, que os valores das frações de nuvens situaram-se entre valores típicos de 20-25\% (estação seca) e 35-40\% (estação chuvosa).

\section{Agradecimentos}

Os autores agradecem ao CNPq por financiar o desenvolvimento desta pesquisa, através de bolsa de Mestrado (134099/2014-1) para o primeiro autor e de produtividade de pesquisa (bolsa PQ 303720/2010-7) para o segundo autor.

\section{Referências}

ALVES, M.A.S.; MACHADO, L.A.T.; PRASAD, G.S.S.D. Estudo da variabilidade de cobertura de nuvens na Amazônia Central. Acta Amazônica, v. 37, n. 1, p. 71-80, 2007.

ALMEIDA, R; SALATI,E.; VILLA NOVA, N.A. Distribuição espectral e coeficiente de transmissão da radiação solar para condições de céu limpo em Manaus. Acta Amazônica, v. 9, n. 2, p. 279-285, 1979.

ARTAXO, P.; RIZZO, L.V.; BRITO, J.F.; BARBOSA, H.M.J.; ARANA, A.; SENA, E.T.; CIRINO, G.G.; BASTOS, W.; MARTIN, S.T.; ANDREAE, M. O. Atmospheric aerosols in Amazonia and land use change: from natural biogenic to biomass burning conditions, Faraday Discuss., p. 203-235, 2013.

BRINKMANN, W.L.F.; WEINMAN, J.A.; RIBEIRO, M.N.G. Air temperatures in Central Amazônia. ActaAmazônica, v. 1, n. 1, p. 75-76, 1971.

BUTT, N.; NEW, M.; MALHI, Y.; COSTA, A.C.L.; OLIVEIRA, P.; ESPEJO, J.E.S. Diffuse radiation and cloud fractions in two contrasting Amazonian rainforest sites. Agricultural and Forest Meteorology, v. 150, n. 3, p. 361-368, 2010.

CIRINO, G.G.; SOUZA, R.A.F.; ADAMS, D.K.; ARTAXO, P. The effect of atmospheric aerosol particles and clouds on net ecosystem exchange in the Amazon. Atmospheric Chemistry and Physics, p. 6523-6543, 2014.

COSTA AZEVEDO, D.; PINTO, M.M.; AZEVEDO, M.L.; Distribuição da radiação solar na região amazônica. In: SIMPÓSIO BRASILEIRO DE ENERGIA SOLAR, 2, 1974, João Pessoa. Anais...João Pessoa: UFPB, 1974. 
CULF, A.D.; ESTEVES, J.L.; MARQUES FILHO, A. DE O. Radiation, Temperature and humidity over forest and pasture in Amazonia. In : GASH, J. H.C., NOBRE, C. A., ROBERTS, J.M., VICTORIA, R.L. Amazonia deforestation and climate. Chicester, UK: John Wiley\& Sons, 1996. p. 175-191.

DOUGHTY, C.E.; FLANNER, M.G.; GOULDEN, M.L. Effect of smoke on subcanopy shaded light, canopy temperature, and carbon dioxide uptake in an Amazon rainforest, Global Biogeochem Cycles, v. 24, n. 3, 2010.

DURIEUX, L.; MACHADO, L.A.T.; LAURENT, H. The impact of deforestation on cloud cover over the Amazon arc of deforestation. Remote Sensing Environment, p.132-140, 2003, (DOI: 10.1016/S0034-4257(03)00095-6).

ECMWF. The 2015/2016 El Nino and beyond. ECMWF Newsletter, 151, p. 16-21, 2017.

FEITOSA, J.R.P.; COSTA, R.F.; FISCH, G.; SILVA, S.S.; NOBRE, C.A. Radiação solar global em áreas de floresta e pastagem na Amazônia. Revista Brasileira de Agrometeorologia, v. 6, n. 1, p. 1-7, 1998.

FISCH, G.; MARENGO, J.A.; NOBRE, C.A. Uma revisão geral do clima da Amazônia. Acta Amazônica, v. 28, n. 2, p. 101-126, 1998.

GOLDMAN, G.H.; FATTORI, A.P.; JANUÁRIO, M.Variação espacial e temporal da irradiância solar e da razão entre vermelho e vermelho-extremo que chegam ao solo em diferentes micro habitats na região de Tucuruí - PA. Acta Amazonica, v. 19, n. 4, p. 243-248, 1989.

MACEDO, A.S. Variabilidade temporal e espacial da radiação solar na região de Manaus - AM durante o experimento

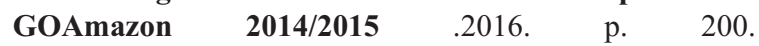
(sid.inpe.br/mtc-m21b/2016/09.20.12.56) - Instituto Nacional de Pesquisas Espaciais (INPE) São José dos Campos, 2015. Disponível em: http://mtc-m21b.sid.inpe.br/col/sid.inpe.br/mtc-m21b/2016 /09.20.12.56/doc/publicacao.pdf. Acesso em: Junho de 2017.

MACHADO, L.A.T.;LAURENT, H.; DESSAY, N.; MIRANDA, I. Seasonal and diurnal variability of convection over the Amazonia: A comparison of different vegetation types and large scale forcing, Theoretical and Applied Climatology, v. 78, p. 61-77.2004.

MARTIN, S.T.; ARTAXO, P.; MACHADO, L.A.T.; MAZNI, A.O.; SOUZA, R.A.F.; SCHUMACHER, C; WANG, J.; ANDREAE M.O.; BARBOSA, H. M. J.; FAN, J.; FISCH, G.; GOLDSTEIN, A.H.; GUENTHER, A.; JIMENEZ, J.L.; POSCHL, U.; SILVA DIAS, M.A.; SMITH, J.N.; WEN-
DISCH, M. Introduction: Observations and Modeling of Green Ocean Amazon (GOAmazon 2014/15).Atmospheric Chemistry and Physics, v. 15, p. 4785-4797, 2016.

MARTIN, S.T., ARTAXO, P.E., MACHADO, L.A.T. MANZI; A.O.; SOUZA, R.A.F.; et al. The Green Ocean Amazon Experiment (GoAmazon2014/5) Observes Pollution Affecting Gases, Aerosols, Clouds, and Rainfall over the Rain Forest. Bulletin of the American Meteorological Society, v. 98, n. 5, p. 981-997, 2017.

PAVÃO, V.M.; QUERINO, C.A.S.; QUERINO, J.K.A.S.; MARTINS, P.A.S.; SIQUEIRA, L.F.; LEITE, L.O.; PASSOS, L.A.; RODRIGUES, T.A.C.; MACHADO, N.G.; BIUDES, M.S. Análise da radiação solar global (rg) e albedo superficial sobre um ecossistema de floresta nativa em Humaitá AM durante o período chuvoso. Revista EDUCAmazônia Educação Sociedade e Meio Ambiente, v.7, n.1, p. 42-56, 2014.

RAP, A.; SPRACKLEN , D.V.; MERCADO, L.; REDDINGTON, C.L.; HAYWOOD, J. M.; ELLIS, R.J.; PHILLIPS, O.L.; ARTAXO, P.; BONAL, D.; RESTREPO COUPE, N.; BUTT, N. Fires increase Amazon forest productivity 94 through increases in diffuse radiation. Geophysics Research Letters, v. 42, p. 4654-4662, 2015.

SALATI, E.; MARQUES, J. Climatology of the Amazon region. In: SIOLI, H. (ed.). The Amazon - limnology and landscape ecology of a mighty tropical river and its basin.Dr. W. Junk Publishers, 1984. $763 \mathrm{p}$.

VILLA NOVA, N.A.; SALATI, E.; MATSUI, E. Estimativa da evapotranspiração na bacia amazônica. Acta Amazônica, v. 6, n 2, p.215-228, 1976.

VILLA NOVA, N.A.; RIBEIRO, M.N.G.; NOBRE, C.A.; SALATI, E. Radiação Solar em Manaus. Acta Amazônica, v. 8, n. 3, p. 417-421, 1978.

YAMASOE, M.A.; VON RANDOW, C.; MANZI, A.O.; SCHAFER, J.S.; ECK, T.F.; HOLBEN, B.N. Effect of smoke and clouds on the transmissivity of photosynthetically active radiation inside the canopy, Atmos. Chem. Phys., v. 6, p. 1645-1656, 2006.

\section{Endereços de Internet}

GOAmazon 2014/15: http:/cam-

paign.arm.gov/goamazon2014.

ARM : http://www.arm.gov.

This is an Open Access article distributed under the terms of the Creative Commons Attribution Non-Commercial License which permits unrestricted non-commercial use, distribution, and reproduction in any medium provided the original work is properly cited. 